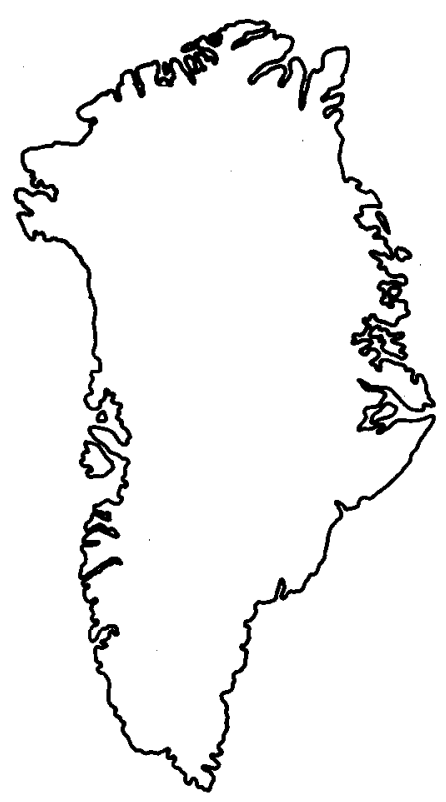

\title{
Silurian biogeography: revision of the North Atlantic Realm in the Llandovery
}

\author{
A.J. Boucot and John M. Hurst
}

\begin{abstract}
Llandovery faunas have been considered more cosmopolitan than any others during the Lower Ordovician - Middle Devonian with only two undivided biogeographic Realms, the North Atlantic and Malvinokaffric, being recognised. Endemic pentameroids known from the Ashgill - Middle Llandovery of the Uralian region, Siberian Platform and adjacent Sette Daban occur commonly in North Greenland. Thus, during this time and in biofacies rich in pentameroids, the North Atlantic Realm appears divisible into a North Atlantic Region and a Uralian-Cordilleran Region, as in the Upper Silurian.
\end{abstract}

A.J.B. Department of Geology, Oregon State University, Corvallis, Oregon 97331, U.S.A.

J.M.H. Grønlands Geologiske Undersøgelse, Øster Voldgade 10, DK-1350 København K, Danmark.

According to Boucot (1975), Llandovery (Lower Silurian) faunas are far more cosmopolitan than those of any other part of the time interval Lower Ordovician to Middle Devonian. Such a situation is reflected by the fact that only two undivided biogeographic Realms, the North Atlantic and the Malvinokaffric are recognisable within the Llandovery. For the Upper Silurian (Wenlock to Pridoli) not only are the two Realms present but the North Atlantic one is divisible into a North Atlantic Region and a Uralian-Cordilleran Region (the Malvinokaffric Realm is undivided throughout the Silurian). The North Atlantic Region includes the area from the west slope of the Urals, to the circum-North Atlantic Region of Europe, North America, northern South America to central Nevada and much of Arctic Canada. In contrast, the Uralian-Cordilleran Region occupies the area from the west slope of the Urals, through northern and central Asia (including Tien Shan and Altai-Sayan), eastern Australia and New Zealand to Arctic North America, Yukon, Nevada and northern California (Boucot, 1975). Up to the present the differentiation of the North Atlantic Realm was thought to occur in the earliest Wenlock.

The purpose of this note is to draw attention to the fact that fossil material derived from the Ashgill (Ordovician), Lower and Middle Llandovery (Silurian) of North Greenland indicates a similar two Region subdivision of the North Atlantic Realm, as already recognised in the Upper Silurian.

The basis for the recognition of this sub-division was initiated by Nikiforova (1960) and Nikiforova \& Andreeva (1961) who described Kulumbella Nikiforova, 1960 an elaborately 


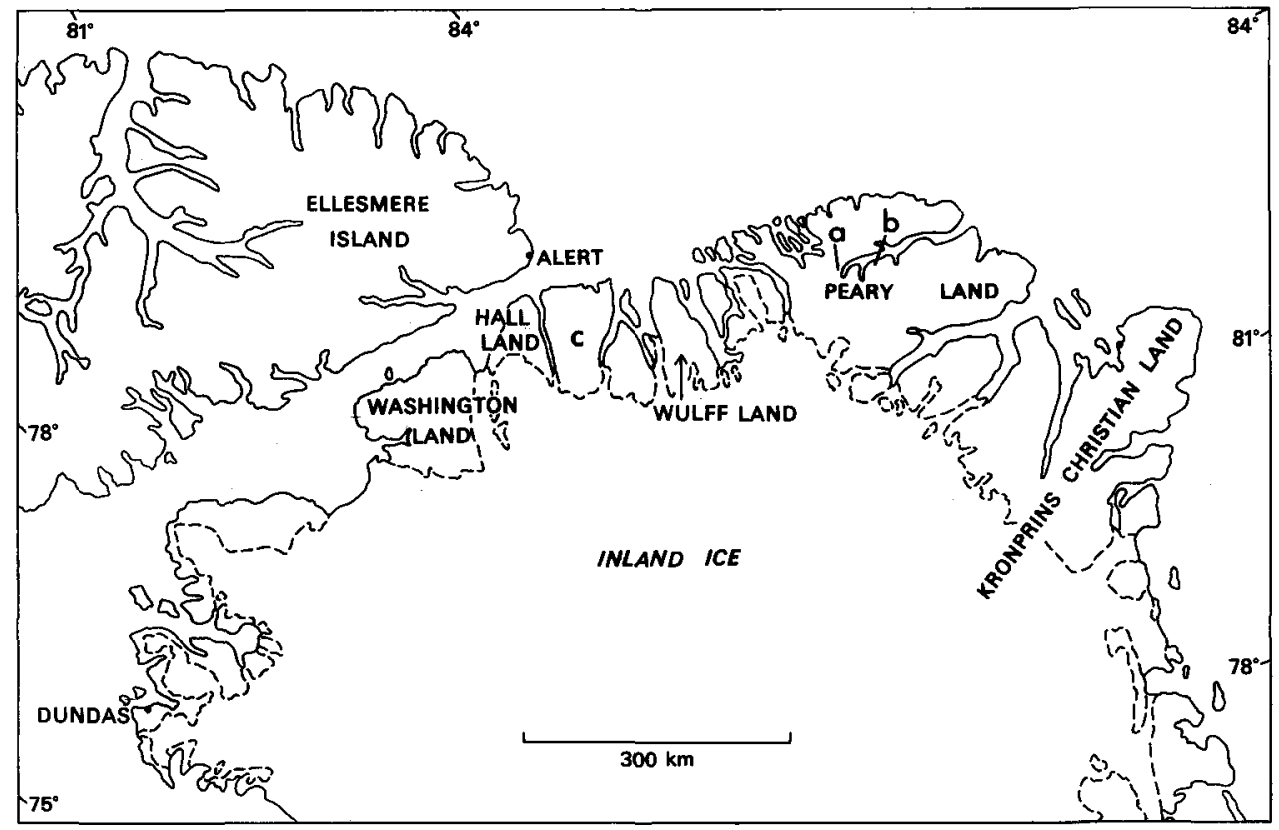

Fig. I. Map of North Greenland indicating localities for pentameroid genera. a, Frederick E. Hyde Fjord; b, Odins Fjord; c, Nyeboe Land.

ornamented, endemic, stricklandiid brachiopod from Middle Llandovery strata of the Siberian platform and the western slope of the Urals. More recently, a number of closely related, smooth and costate virgianid brachiopod genera from the Ashgill to Middle Llandovery of the Urals and the Asiatic part of the Soviet Union have been erected. These include Virgianella Nikiforova \& Sapelnikov, 1971, Pseudoconchidium Nikiforova \& Sapelnikov, 1971, Eoconchidium Rozman, 1967, Tcherskidium Nikolaev \& Sapelnikov, 1969 and Proconchidium Sapelnikov, 1969 (Rozman, 1967; Nikolaev \& Sapelnikov, 1969; Nikiforova \& Sapelnikov, 1971; Modzalevskaya \& Sapelnikov, 1973; and Rukavishnikova \& Sapelnikov, 1973). At this juncture it should be pointed out that Boucot et al. (1971) earlier considered Tcherskidium and Proconchidium to be synonyms of Eoconchidium.

These endemic genera are restricted to the interval Ashgill to Middle Llandovery. There is no evidence for them within the Upper Llandovery of the Uralian Siberian platform regions.

Recent work in the North Greenland Silurian has located a number of these virgianid genera, plus what are undoubtedly some additional genera of related type, and the stricklandiid genus Kulumbella in strata of Ashgill to Middle Llandovery age. The genera and their geographic distribution (fig. 1) include:

(1) Pseudoconchidium. At present only known from Frederick E. Hyde Fjord, northern Peary Land.

(2) Eoconchidium. Hall Land and Nyeboe Land.

(3) Virgianella. Odins Fjord, western Peary Land. 
(4) New genus. Morphologically it possesses a very long pedicle valve septum, as does Eoconchidium. However, the valve configuration is close to Virgianella, while the very fine radial costae appear to be of a new type. Known from Frederick E. Hyde Fjord, northern Peary Land.

(5) New genus. Morphologically it is internally like Virgiana and externally like Eoconchidium. Known from Wulff Land and Peary Land.

(6) Kulumbella. Only known from Odins Fjord, western Peary Land.

The presence of these endemic virgianids in the Uralian region, the Siberian Platform and adjacent regions as the Sette Daban, as well as North Greenland, during Ashgill, Lower and Middle Llandovery time reflects a level of provincialism previously unknown in the Lower Silurian. For the Upper Silurian a North Atlantic Region and a Uralian-Cordilleran Region have been identified (Boucot, 1975). These two major sub-divisions of the North Silurian Realm were previously identified as appearing in the earliest Wenlock; the Llandovery of the Realm being completely cosmopolitan with the exception of a very limited number of rare, endemic genera. However, it is now apparent that this two Region sub-division applicable in the Upper Silurian may also be used, at least within those biofacies of the Lower Silurian rich in pentameroids (virgianids). It is also apparent that Ashgill age precursors of these two Lower and Middle Llandovery sub-divisions were present within the same areas.

Previous failure to recognise these two Region level sub-divisions within the Lower Silurian is chiefly due to the fact that Llandovery age shelly bed facies are poorly developed in the total area of the Uralian-Cordilleran Region. For example, in Nevada and adjacent regions the Lower and Middle Llandovery is known almost totally from graptolitic facies, rendering it impossible to locate the critical pentameroids (Berry \& Boucot, 1970; Berry \& Murphy, 1975; Johnson et al., 1976). In Canada from British Columbia and the Yukon through the Arctic Islands the critical age beds are represented by sequences of barren dolomite (mainly the Cornwallis dolomite; see Thorsteinsson, 1958). The Llandovery is only represented by graptolitic facies in Czechoslovakia and the Carnic Alps (Horný, 1962) as is the case in North Africa (Berry \& Boucot, 1973). In most of the central and southern Urals beds of the requisite age are either represented by graptolitic facies or dolomitic rocks (Boucot, 1969).

It is still unknown whether the non pentameroid rich communities and biofacies of the Lower Llandovery are similarly endemic. Further, there is still uncertainty as to whether this Region level endemism affects the Upper Llandovery. By drawing a parallel with the Upper Silurian, the non pentameroid rich communities may also be expected to display Region level endemism in the Lower and Middle Llandovery.

The Upper Llandovery is in many ways even more puzzling. Many pentamerids have been recorded from the Siberian Platform and North Greenland, but at this moment it is impossible to recognise a highly endemic group of pentamerid genera. It is probable that the Upper Llandovery was far more cosmopolitan than either the interval Lower to Middle Llandovery or the Upper Silurian.

From an evolutionary viewpoint there is a radiation of both smooth and strongly costate virgianid genera during the interval Ashgill to Middle Llandovery. A terminal extinction event affecting most of the genera occured prior to the Upper Llandovery. The only exceptions are the few smooth virgianids which are ancestoral to the smooth pentamerids of the Upper Llandovery (Berry \& Boucot, 1970 p. 30). During the Upper Llandovery and earliest Wenlock there was a second radiation of smooth Pentameridae rather than smooth Virgianidae, resulting in a complex of Upper Wenlock to Pridoli age smooth and costate genera (Boucot \& Johnson, 1979). 


\section{References}

Berry, W.B.N. \& Murphy, M.A. 1975: Silurian and Devonian graptolites of central Nevada. Univ. Calif. Publ. geol. Sci. 110, 1-109.

Berry, W.B.N. \& Boucot, A.J. 1970: Correlation of North American Silurian rocks. Spec. Pap. geol. Soc. Amer. 102, 1-289.

Berry, W.B.N. \& Boucot, A.J. 1973: Correlation of the African Silurian rocks. Spec. Pap. geol. Soc. Amer. 147, 1-83.

Boucot, A.J. 1969: The Soviet Silurian: recent impressions. Bull. geol. Soc. Am. 80, 1155-1162.

Boucot, A.J. 1975: Evolution and Extinction Rate Controls. Elsevier, Amsterdam, 427 pp.

Boucot, A.J. \& Johnson, J.G. 1979: Pentamerinae (Silurian Brachiopoda). Palaeontographica 163, 87-129.

Boucot, A.J., Johnson, J.G. \& Rubel, M. 1971: Descriptions of brachiopod genera of subfamily Virgianinae Boucot et Amsden, 1963. Eesti Teaduste Akad. Toimetised, 20, Keem.-Geol., 271-280.

Horný, R.J. 1962: Das Mittelböhmische Silur. Geologie, Berl. 11(8), 873-916.

Johnson, J.G., Boucot, A.J. \& Murphy, M.A. 1976: Wenlockian and Ludlovian age brachiopods from the Roberts Mountain Formation of central Nevada. Univ. Calif. Publ. geol. Sci. 115, 1-102.

Modzalevskaya, T.L. \& Sapelnikov, V.P. 1973: Proconchidium munsteri Pechorskogo Urala (Proconchidium munsteri from the Pechora Urals). In Fauna i biostratigrafia sredngo i verkhnego Paleozoya Ural. (Fauna and biostratigraphy of the middle and upper Palaeozoic of the Pechora Urals). Trudy Sverdlovsk. gorn. Inst. 93, 58-62.

Nikiforova, O.I. 1960: Novi Rod Kulumbella iz Semeistva Stricklandidae, Paleont. Zh. 1960 (3), 61-65.

Nikiforova, O.I. \& Andreeva, O.N. 1961: Stratigrafia Ordovicika Silura Sibirskoi platformi i ee paleontologischeskoe obosnovanie (Brackhipodi). Trudy vses. nauchno.-issled. geol. Inst. 56, $412 \mathrm{pp}$.

Nikiforova, O.I. \& Sapelnikov, V.P. 1971: Novye rannesiluriyskiye Virgianidae (Brachiopods). [New Early Silurian Virgianidae Brachiopods]. Paleont. Zh. 1971 (2), 47-56. (Translation in Paleontol. J. 5(2), 181-190).

Nikolaev, A.A. \& Sapelnikov, V.P. 1969: Dva novykh roda pozdneordovikskikh Virgianidae [Two new genera of Late Ordovician Virgianidae]. In Problems of the Geology and Hydrogeology of the Urals. Trudy Sverdlovsk. gorn. Inst. 63, 11-17.

Rozman, Kh.S. 1967: Novyi rannepaleozoyskiy rod Eoconchidium (Pentameracea) Selennyakhskogo dryazha (Severovostok, SSSR). [New Early Paleozoic genus Eoconchidium (Pentameracea) from the Selennyakh Ridge, Northeastern USSR]. Paleont. Zh. 1967 (2), 62-68. (Translation in Paleontol. J. 1(2), 52-58).

Rukavishnikova, T.B. \& Sapelnikov, V.P. 1973: Novye Pozdeashgillskiye Pentameracea Kazakhtstana [New Late Ashgill Pentameracea of Kazakhstan]. In Fauna i biostratigrafia srednogo i verkhnogo Paleozoya Urala. Trudy Sverdlovsk. gorn. Inst. 93, 48-135.

Thorsteinsson, R. 1958: Cornwallis and Little Cornwallis Islands, District of Franklin, Northwest Territories. Mem. geol. Surv. Can. 294, 134 pp. 